\title{
ランチョンセミナー 2
}

\section{LS2}

\section{RA 治療の戦略的アプローチ}

\author{
慶應義塾大学医学部 リウマチ内科
}

竹内勤

現在，我々はRA に対し生物学的製剂を含めた抗リウマチ薬を用い，寛解を目指す治療を行っている，将来 的には早期診断が進展し, 予防医療, 先制医療や個別化医療, 精密医療が未来の治療戦略候補になるものの, 現状は利用可能な薬剤を駆使して効果最大化に努める必要がある.

これまでの治療戦略は，MTX をべースに効果不十分であればTNF 阻害薬を加えてきた。これは我々の研究 で, TNF 阻害薬単独治療に比べTNF 阻害薬併用治療が高い効果を発揮するという臨床データから分かってき た事である。

一方，IL-6 シグナルを遮断する Tocilizumab（TCZ）を用いた SURPRISE study は，MTX 不応例に TCZ 追加 する群と TCZに切り替えた単剤群の 2 群の多施設前向き無作為化オープンラベル群間試験である. 24 週まで は追加群で活動性改善が得られたが，52 週では単凨群で同様の改善効果を認めた。この結果は MTX 無効例に 対しMTXと TCZにて治療介入し, 治療効果が得られた後にMTX を減量していくという新たな治療戦略を示 唆する興味深いものと言える.

最新の研究では, pSTAT3 と TCZの関係も分かってきた一方, Treg と疾患活動性の関係も明らかになって いる，本講演では Clinical Evidence と Translational Research を併せて IL-6 シグナル抑制の意義を踏まえ， RA 治療の最適化について解説する。 